\title{
RECENT ADVANCES IN THE TREATMENT OF RENAL DISEASE
}

\author{
By A. G. SPENCER, G.M , M.D., M.R.C.P. \\ Reader in Medicine in the University of London; Physician, St. Bartholomev's Hospital, London
}

This has been a decade of outstanding discoveries made in the study of renal disorders, and an exciting prospect steadily grows of the great improvement in therapy that will certainly follow. Within the limits of a brief review it is not possible to describe the many advances that have been made, and any attempt at a detailed synoptic description of modern therapeutic regimes would be misleading. The aim of this review will be restricted, therefore, to indicate the directions in which progress in treatment has been made, together with the background of experimental pathology and clinical observation on which these advances are based. The details may be found in the papers to which reference is made, and the bibliography provides a short guide to the recent literature on renal disease.

Progress largely waits on technical innovation. The new techniques which have revolutionized the study of renal function and disease are numerous in every branch of medical science. In anatomy, renal biopsy (Lancet, 1959) and the use of the electron microscope (Rhodin, 1958), micro-dissection of the nephron (Darmady and Stranack, 1957), and the development of histochemical methods (Pearse, I953) have given us new ideas on old diseases. In physiology, renal clearance techniques and especially those concerned with tubular function (Mudge, 1958; Stanbury, 1958; Black and Emery, I957) and the enzymatic basis of tubular transport (Taggart, -1958) are changing our ideas of renal homeostasis. Much of the progress in renal physiology stems from the medical use of the flame-photometer. The application of paper chromatography to the study of renal disorders (Dent, 1954; Harris, 1957) has led to the discovery of new diseases, and the biochemical basis and hereditary nature of long recognized syndromes. In endocrinology the assay of electrolyte controlling hormones (Spencer, I950), the discovery of their role in oedema (Deeming and Leutscher, 1950), and the eventual isolation of aldosterone (Simpson, Tait and Bush, 1952) has led to a radical change in concepts of sodium and $\overrightarrow{\vec{\omega}}$ potassium metabolism. The synthesis of new $\frac{\Omega}{D}$ anti-inflammatory steroids (Riley, 1959) willo probably be followed by their use in the treatment of several varieties of nephritis. In radiology the development of renal angiography (Seldinger, $\overrightarrow{0}$ 1953; Murray and Tressider, 1957), renal venography (Steiner, 1957), and the use of image $\frac{\sigma}{N}$ intensifiers to permit cineradiography has greatly assisted in the diagnosis of renal vascular disease and in the study of pyelitis associated wi $\vec{Z}$ ureteric reflux. In pathology the use of fluores cent and radioactive-labelled antigens has been fruitful in the study of experimental nephrit (Krakower and Greenspan, 1958). The role of the ischaemic kidney in the production of hyper $\overrightarrow{0}$ tension is still uncertain ("Proceedings of the Conference on Basic Mechanisms of Arteria Hypertension,' 1958), but the importance of treating hypertension in renal disease is now well established (Wilson and Abrahams, 1957).

\section{Acute Glomerulo-nephritis}

The aetiology and pathogenesis of acute glomerulo-nephritis have recently been considered in detail (Schmidt and Rammelkamp, 1958; Lancet, 1958). The relation between acute nephritis in man and experimental nephritis in animals produced by nephrotoxic antigens (Krakower and Greenspan, 1958) or by anaphylactic 3 hypersensitivity (Rich, 1956) is not clear. However, the role of the streptococcus in human nephritis is demonstrated by the association of $\mathrm{O}$ acute glomerulo-nephritis with a previous infection by a type (usually type 12 or 4 ) specific streptococcus (Rammelkamp and Weaver, 1953; Wilmers, Cunliffe and Williams, 1954), by the $\mathcal{N}$ epidemic nature of the disease (Rammelkamp, $N$ 1955; Pleydell and Turner, 1958), and by the N high antistreptolysin titre of the serum (Loeb, $\sigma$ 1938; Seegal and Lyttle, 1933). The demonstration that streptococci can convert nephrotoxic haptens into complete antigens (Glynn et al., 足 I956) and the finding of antibodies to human 
kidney tissue in the serum of patients recovering from glomerulo-nephritis (Lange, Slobody and Strong, 1955) does suggest that streptococci can initiate an auto-immune process. Renal biopsy during the acute phase of nephritis has changed our concepts of the pathological histology (Hutt, Pinniger and de Wardener, I958), emphasizing the involvement of the renal tubules and interstitial tissue in addition to the glomerular lesions.

In diagnosis care should be taken to differentiate acute glomerulo-nephritis from pyelonephritis, focal nephritis, polyarteritis, anaphylactcid purpura, hereditary forms of pyelonephritis and glomerulo-nephritis (Robin and Gardner, 1957), and blood diseases in which recurrent haematuria may occur, such as sickle-cell anaemia (Mostogi, Bruegge and Diggs, 1957).

In treatmert there are five main considerations: diet, and the use of diuretics, artibiotics, hypotensive drugs and steroid therapy. Mild cases need only a low salt diet as long as oedema is present (Illingworth, I954). When the kidneys are severely affected the intake of protein, salt, potassium and water must be restricted (Nabarro and Spencer, 1951; Spencer and Franglen, 1952). This type of dietary treatment has completely changed the clinical course of severe acute glomerulo-nephritis. Gross anasarca, heart failure and convulsions from cerebral oedema were formerly common and fatal, but are now rare, and the prognosis is good (Clark, I956). Complete renal failure is very uncommon in acute nephritis and is an indication for haemodialysis.

Diuretics are seldom required and, except in the subacute stage of glomerulo-nephritis and in patients with only a slightly raised blood urea, they are rarely effective. Schreiner and Bloomer (1957) have reported some excellent responses to chlorothiazide in this group of patients.

Penicillin is usually given but has little apparent effect on the illness. Rammelkamp (1955) has emphasized the value of penicillin in reducing the attack rate during a nephritogenic streptococcal epidemic, and also advocates the prevention of recurrences by long-term penicillin- $\mathrm{V}, 200,000$ units b.d. until the child has left school. In the author's experience penicillin is effective in the prevention of attacks of recurrent focal nephritis.

Hypotensive drugs are usually unnecessary, but in patients with pulmonary oedema or encephalopathy the cautious use of intravenous hexamethonium is invaluable. Etteldorf, Smith and Johnson (1956) used reserpine, or hydralzine and reserpine, in acute nephritis and state that all the patients become normotensive without undesirable side-effects.

The early reports of adrenal steroid therapy in

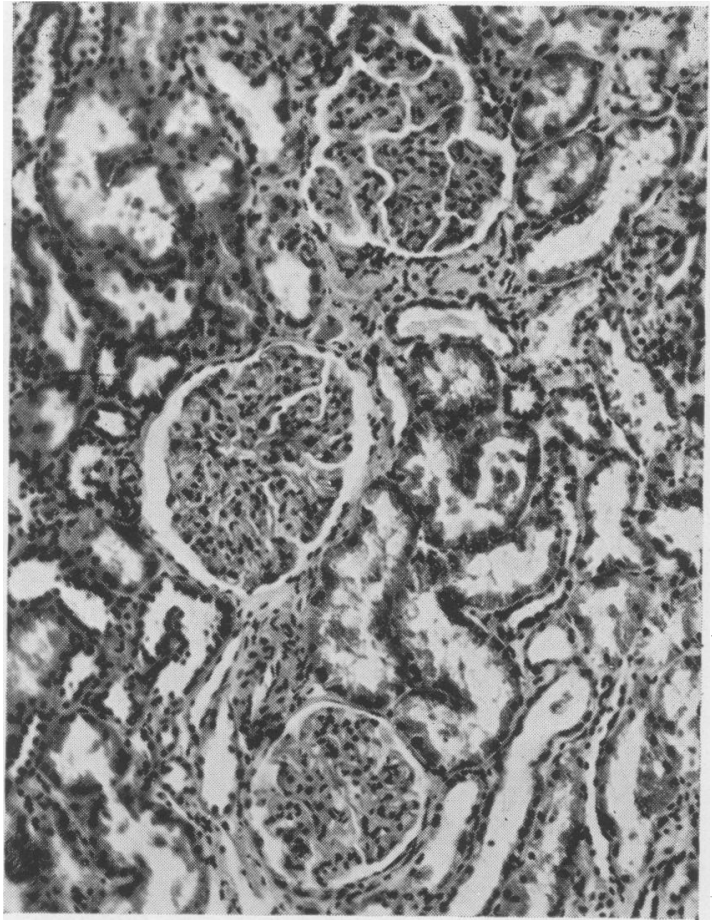

FIG. I.-Renal biopsy in the nephrotic syndrome. H. \& E. $\times$ 150. 'Twelve glomeru'i were obtained and show advanced changes of a membranous nephritis. The renal tubules contain amorphous coagulated protein.

acute glomerulo-nephritis were not encouraging (Farnsworth, 1950). Their use in subacute glomerulo-nephritis is usually much less successful than in Type II nephritis and in membranous glomerulo-nephritis, but good results have been obtained with corticotrophin (Lange, Slobody and Strong, 1955) with cortisone, prednisone and triamcinolone (Lange and Wasserman, 1958), and with dexamethasone (Riley, I959).

\section{The Nephrotic Syndrome}

It is now well recognized that the nephrotic syndrome is not a disease entity. In a series of 246 patients with this syndrome at U.C.H. the aetiological diagnosis was as follows:

I. Type II nephritis . . . . . . 118

2. Diabetic glomerulosclerosis $\quad \ldots \quad 57$

3. Subacute Type I nephritis _. 2 I

4. Amyloid disease .. $\quad . \quad \ldots \quad$ I9

5. Disseminated lupus erythematosis 9

6. Drugs-Mercury .. .. .. 4 Gold $\quad . . \quad \ldots \quad \ldots \quad 4$ $\begin{array}{llll}\text { Tridione .. } & \ldots & \ldots & \mathbf{I}\end{array}$

7. Thrombosis of the renal vein $\quad \ldots \quad 2$

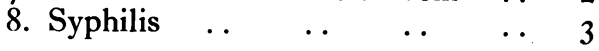


9. Pyelonephritis $\ldots \quad$. . $\quad \ldots \quad 2$

Io. Tricuspid incompetence .. .. I

I I. Myelomatosis . . $\quad \ldots \quad \ldots \quad$ I

I2. Radiation nephritis $\ldots \quad \ldots \quad$ I

13. Unclassified $\quad \ldots \quad \ldots \quad \ldots 3$

This heterogeneity underlines the need for renal biopsy in diagnosis, prognosis and treatment (Muehrcke, Kark and Pirani, I955; Lancet, I959). For example, where the biopsy reveals amyloid disease (Kark et al., I958) chronic Type I glomerulo-nephritis or a fully developed membranous nephritis (Fig. I) the prognosis is poor and treatment with steroids is not likely to be effective. Normal histological methods often show only minor changes, while electron microscopy reveals a characteristic loss of the pedicels of the epithelial cells of the glomerular tuft (Farquhar, Vernier and Good, I957). A review of the pathological physiology is given by Squire (1955), and of more recent cbservations by Metcoff (1957) and Derow (1958).

The basis of treatment is by diet and by the use of diuretics, antibiotics and steroid therapy. A high protein (Blarney, I954) low-salt diet (Rosenheim and Spencer, 1956), with or without cation exchange resins, will abolish the oedema in most patients, but when it persists chlorothiazide $250 \mathrm{mg}$. every six hours for 3-5 days (Schreiner, I957; Laragh et al., I958) with potassium supplements is often effective. The use of antibiotics has completely altered the natural history of the nephrotic syndrome in children (Janeway, I957). Death from pneumococcal and other infections formerly accounted for 83 per cent. of these patients, but this is now rare, renal failure being the mode of termination of the progressive disease. Established infections are treated with a full course of antibacterial drug and Penicillin-V, 200,000 units b.d., is given as a long-term prophylaxis until the serum $\gamma$-globulins have returned to normal.

The use of ACTH and synthetic adrenal steroids in the treatment of the idiopathic nephrotic syndrome has recently been reviewed (Derow, I958; Goodman and Baxter, I958; Riley, 1959). The choice of hormone, the dosage and the duration of therapy are not finally established.

An initial course of 10-20 days of oral prednisone 10-20 mg. every six hours, followed by $40 \mathrm{mg}$. a day for three days a week during the next 6-12 months, is a regime commonly used with success. This treatment requires admission to hospital with full biochemical control. The steroids should not be stopped when the odema has gone, but should be continued for at least three months after proteinuria is minimal and the serum proteins have returned to normal. The reduced salt-retaining action of the delta-I steroids allows a less restricted sodium intake. During the continuous steroid course a broad spectrum antibacterial drug should be given, and a mixture containing potassium chloride and citrate, I $g$. six-hourly. Dexamethasone is stated to be effective in the treatment of childhood nephrosis (Riley, I959), but a warning concerning its metabolic effects has already appeared (Slater and Nabarro, I 959).

The eventual prognosis of patients treated with steroids is still uncertain. In children a remission rate of 60 per cent. can be expected, which compares favourably with a mortality rate of 50-60 per cent. in patients not treated with steroids (Goodman and Baxter, 1958). Because of the great heterogeneity of any group of adult nephrotic patients the assessment of treatment and prognosis is much more uncertain. Nevertheless, when the renal biopsy is compatible with a diagnosis of Type II nephritis or of an early membranous nephritis, long-term steroid treatment should be given.

\section{Pyelonephritis}

Pyelonephritis is certainly the commonest oB all renal diseases. Of I,9 I patients admitte with nephritis to U.C.H., 87I were suffering from varieties of pyelonephritis. The experimenta渎 and natural pathology of this disease has been. discussed by Beeson (195.5, 1957), De Navesque (1956) and Brod (1956). Excellent general clinical reviews are provided by Rosenheim (1954), Derow (1956) and Keefer (1957). Chronic pyelonephritis is often a silent disease presenting terminally with hypertension or uraemia (Rosenheim, I954; Platt, I948; Kass, I956, I957) and renal biopsy may be necessary to establish the diagnosis at a stage when the disease can be treated effectively (Kipnis et al., 1955; Muehrcke et al., 1955; Kark et al., 1958). In recurrent urinary infections great care must be taken to detect hidden abnormalities of the urinary tract such as diverticulae of the urethra and bladder, uretero-vesical reflux, anomalous ureteric drainage and supernumerary kidneys, as well as the common stones and obstructive lesions. When there is a secondary urinary infection renal tuberculosis is easily overlooked. In children, spina bifida occulta and other forms of neurological bladder dysfunction, urethral valves, and varieties of megacystis and megaureter may require reconstructive surgery (Higgins, Williams and Ellison Nash, I95I).

There are three main aims of treatment: the eradication of infection, the relief of hypertension and compensation for the destruction of nephrons and disorder of renal tubular function. 


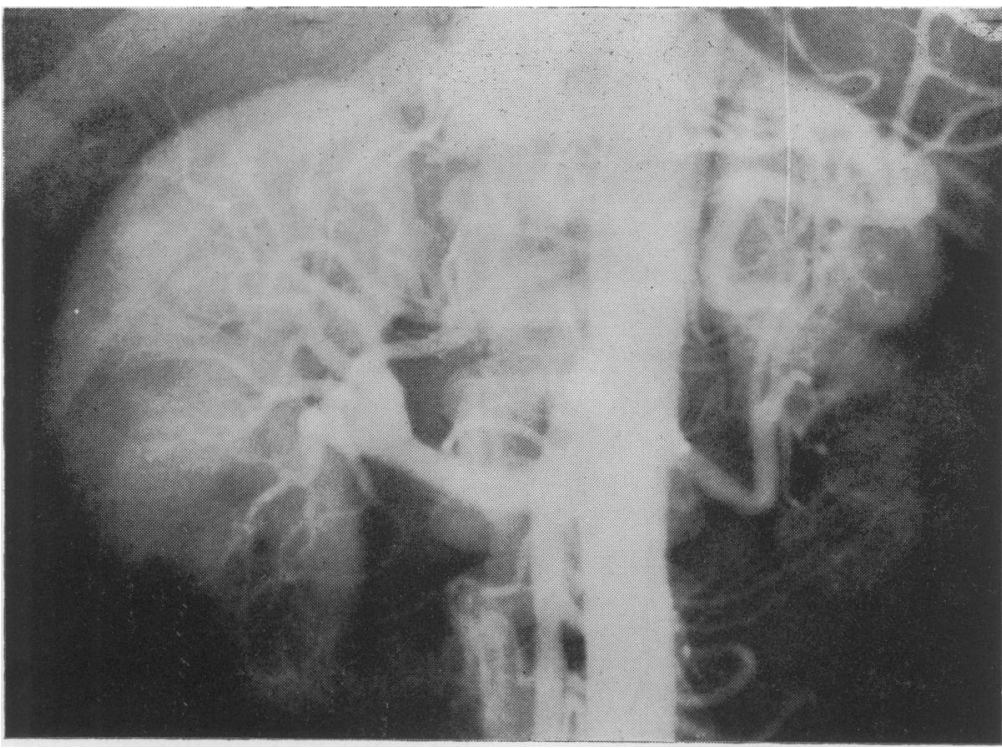

Fig. 2.-Renal angiograin obtained in a patient with severe hypertension. The right kidney and its arterial system is normal. The lower half of the left kidney is shrunken, avascular and with a poor cortical flush. Nephrectomy permanently relieved the hypertension.

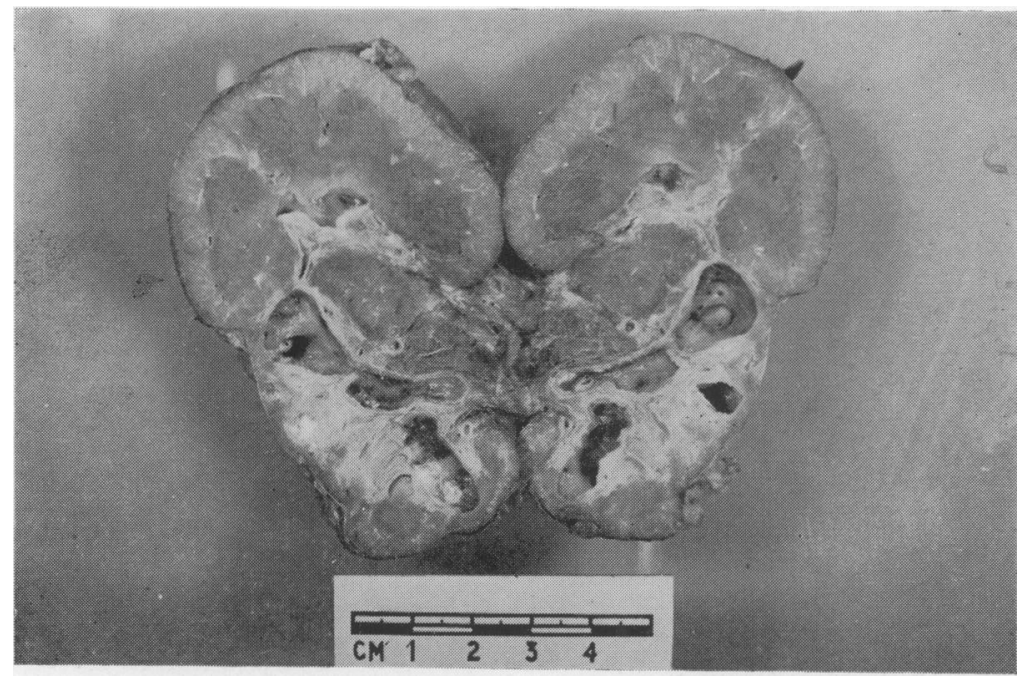

Fig. 3.- The bisected left kidney showing the grossly diseased power pole corresponding accurately with the appearances on renal angiography.

\section{Control of Infection}

The antibacterial treatment of pyelonephritis is discussed by Garrod, Shooter and Curwen (1954); Kass (1955, 1957), Derow (1956) and Garrod (1959). Acute symptomatic pyelonephritis is most often due to a single bacterial species of $E$. coli. Urine culture and antimicrobial sensitivity tests should be carried out and Kass (1957) has also stressed the advantages of quantitative bacterial counts. Sulphadimidine, I g. six-hourly for 7-10 days, is effective against most $E$. coli. No additional benefit is gained by the use of expensive proprietary mixtures of sulphanamides (Brit. med. F., 1959). Nitrofurantoin (Richards et al., 1955) has a wide therapeutic use in infections with E. coli, Proteus vulgaris, Strep. faecalis, 


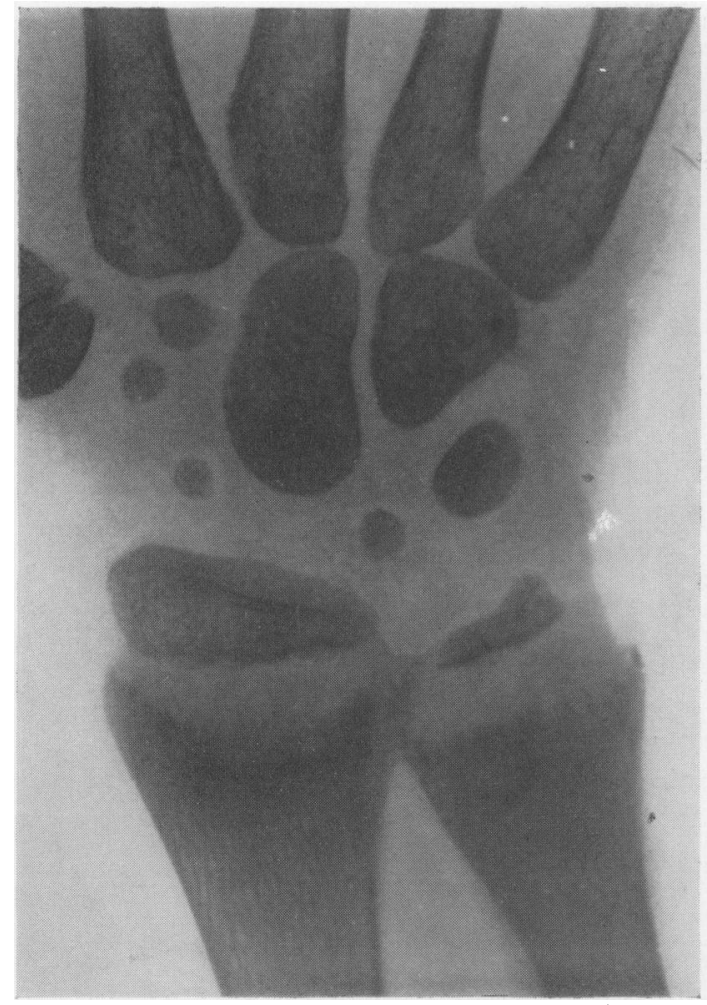

(a)

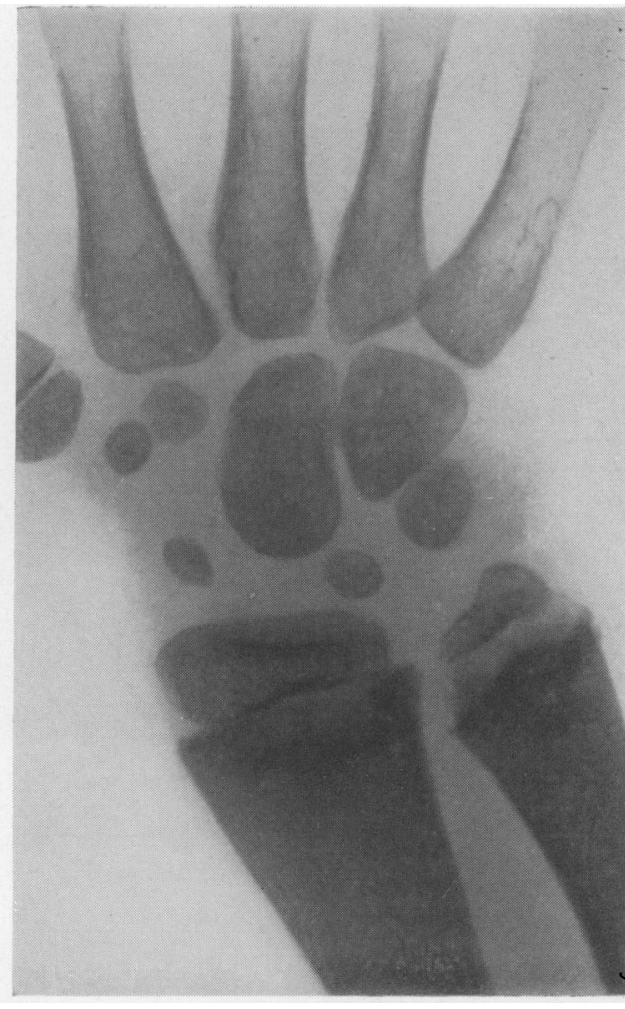

(b)

Fig. 4.-Renal osteodystrophy with renal rickets. (a) untreated; $(b)$ treated.

Aerobacter aerogenes and some staphylocci. A course of $100 \mathrm{mg}$. four times a day for ten days does not often cause a gastro-intestinal upset provided the tablets are taken with meals. It should be noted that the sulphonamides and nitrofurantoin are only bacteriostatic drugs and there may be a reduced incidence of recurrent infection if they are followed by a course of one of the bacteriocidal antibiotics, streptomycin, penicillin and neomycin. Streptomycin is active against many gram-negative organisms and provided the renal function has been ascertained to be normal $\mathbf{I} g$. a day for five days may be given and sufficient alkali to raise the fresh urine to a $\mathrm{pH}$ of 7.5 . If the blood urea is high the dose must be greatly reduced (e.g. 0.25 g./day at a blood urea of $75 \mathrm{mg}$./ $100 \mathrm{ml}$.), otherwise toxic blood leve!s will inevitably be attained.

Penicillin is effective against staphylococcal urinary infections (Scowen, Badenoch and Shooter, 1957), and in high dosage against many enterococci. Neomycin is rapidly bacteriocidal against a great variety of organisms and bacterial resistance rarely develops. Coliform organisms, staphylococci and proteus species are usually highly sensitive and there appears to be little risk of toxicity in a five-day course (Waksman, 1958). Novobiocin (Bauer, 1957) is also effective against organisms resistant to other antibacterial drugs and is useful in the treatment of recurrent proteus infections of the urinary tract. With all these antibiotics and antibacterial agents the urine should be kept alkaline, except when mandelic acid preparations are used. In recurrent and chronic pyelonephritis it is often difficult to cure the infection. The most useful treatment then is continuous sulphadimidine prophylaxis ( $\mathrm{I} \mathrm{g}$. b.d.) combined with intermittent short courses of a bacteriocidal antibiotic. Renal biopsy has demonstrated the extent of the involvement of the interstitial renal tissues in these patients and underlines the ineffectiveness of small doses of bacteriostatic drugs, which keep the urine sterile while allowing the disease to progress.

\section{Pyelonephritis and Hypertension}

When pyelonephritis is associated with hypertension two questions always arise. First, the 0 effect of lowering the blood pressure on renal function, and second, the possibility of a uni- 


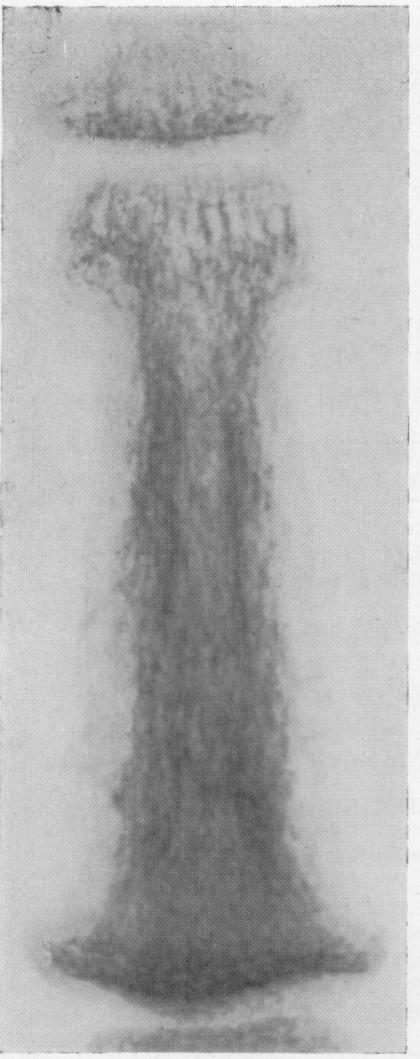

(a)

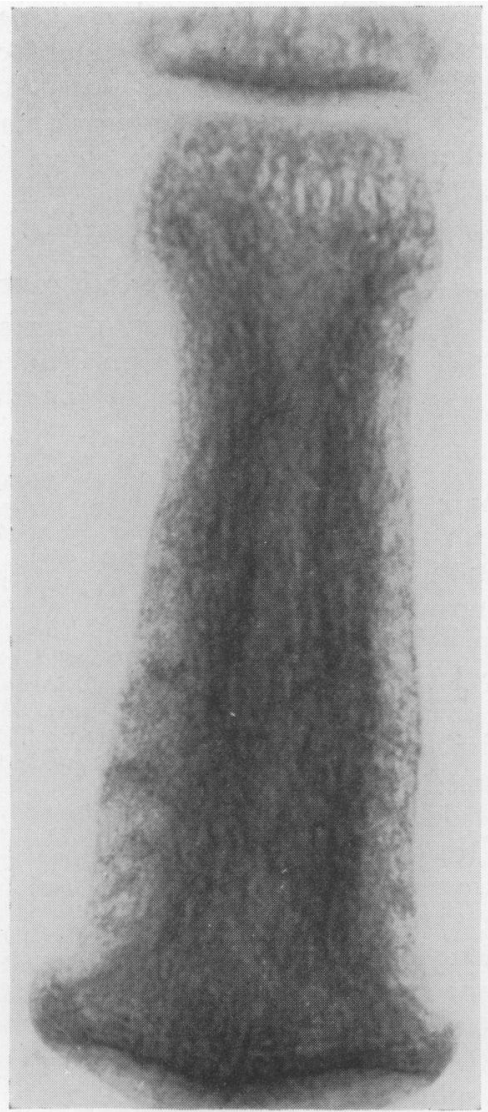

(b)

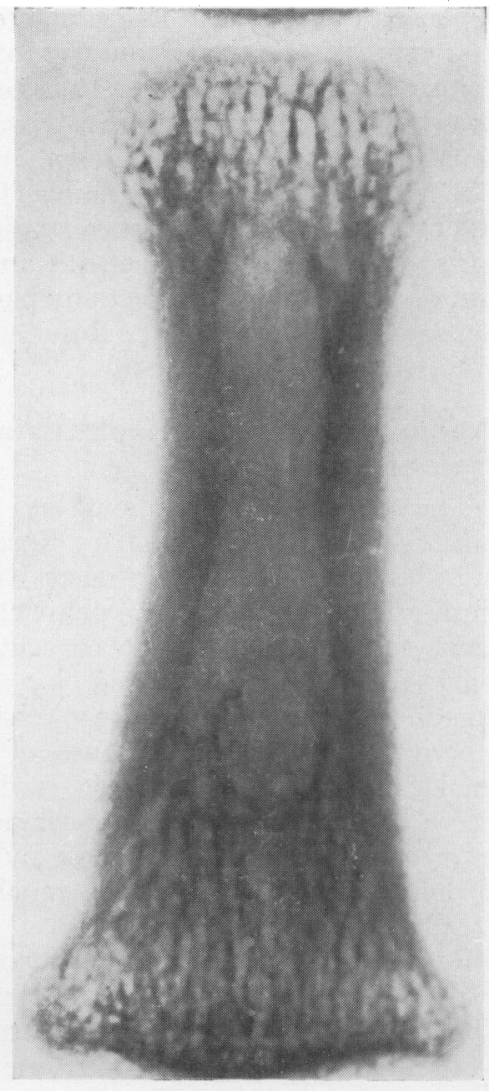

(c)

Fig. 5.-Renal osteodystrophy with secondary hyperparathyroidism. Subperiosteal erosions of the phalanges (a) untreated; (b) partly treated; (c) treatment complete.

lateral renal lesion as the cause of the hypertension, and of its relief by nephrectomy.

There is clear experimental evidence that hypertension damages the arterioles of the kidney, leading to progressive deterioration in renal function (Wilson, I953). Harrington and Rosenheim (1954) found that it was sometimes possible to reduce the blood pressure in patients with renal disease by hypotensive drugs, and this has been confirmed (Wilson and Abrahams, 1957). Care is necessary as some patients with renal disease are remarkably sensitive to ganglion blocking agents (Harrington, 1953) and there is also a delayed excretion and consequent accumulation of these drugs. The renal haemodynamic effects of hypotensive drugs have been studied extensively. Oral reserpine produces no change in the renal blood flow (Moyer, 1954), hydrallazine may increase renal blood flow (Mackinnon, 1952), whereas ganglion blocking drugs may reduce the glomerular filtration rate and the renal plasma flow (Moyer and Mills, I953; Mackinnon, 1952). Provided that the blood pressure is not too drastically reduced hypotensive drugs produce only minor changes in the renal haemodynamics (McDonald and Goldberg, 1957). A combination of reserpine (I mg. stat. followed by $0.1 \mathrm{mg}$. t.d.s.) and pempidine tartrate ( $1.25-5 \mathrm{mg}$. every four hours) is often effective in chronic pyelonephritis, lowering the blood pressure and thereby relieving headache, improving the ocular fundi and assisting the treatment of left-sided and congestive heart failure. However, in very longstanding severe hypertension these drugs are commonly ineffective.

The problems of unilateral 'pyelonephritis' and hypertension are too large to be discussed in this paper. Smith (1956) has provided an extensive clinical review and the theoretical aspects are considered in detail in the "Proceedings of the Conference on Basic Mechanisms of Arterial Hypertension' (1958). Poutasse, in a series of 
papers (Poutasse and Dunstan, 1957, for refs.) has emphasized the frequency of renal artery lesions as the cause of hypertension, their detection by aortography and the cure of the high blood pressure by reconstructive arterial surgery. The value of renal angiography (Figs. 2 and 3 ) and of divided renal clearance studies in the diagnosis of unilateral pyelonephritis and in the selection of patients for nephrectomy has been investigated and discussed by Rosenheim, Spencer, Moulton and Cattell (1959).

\section{Uraemia in Chronic Nephritis and Pyelonephritis}

The general management of chronic renal failure has been discussed by Rosenheim (I95I) and Bull (1955). The intracaval infusion technique and the use of sodium phase cation exchange resins in the management of acute episodes of renal failure are described by Shaw (1959). Freedman and Spencer (1957) have given the experimental basis for the use of androgens in renal failure. Haemodialysis is discussed elsewhere in this issue. The importance of delaying progressive renal arterial disease by the treatment of hypertension in chronic renal disease has already been discussed.

Renal tubular disorders are common in all forms of chronic nephritis and pyelonephritis. The recognition and correct treatment of these syndromes may greatly contribute to the wellbeing of the patient. This fascinating subject is too large to be considered in this paper and the reader is referred to the reviews by Mudge (1958) and Stanbury (1958). The most important are the sodium losing syndrome, that of chronic renal potassium depletion, and the tubular and glomerular renal osteodystrophies (Figs. 4 and 5) (Dent and Hodson, 1954; Dent and Harris, 1956; Stanbury, 1957).

The anaemia of chronic renal disease is partly due to an increased rate of red cell destruction but mainly to a depression of erythropoiesis (Loge, Lange and Moore, 1958). This may be caused by a failure in production of renal erythropoietin (Goldwasser, Fried and Plzak, 1957; Osnes, 1958). It does not respond to the administration of iron, folic acid, cyanocobalamine, cobalt or androgens (Freedman and Spencer, 1958), and can at present only be corrected by blood transfusions. If the anaemia is severe transfusion may greatly improve the general condition of the patient and the renal function. However, Emerson and Burrows (1949) have shown that renal function is not significantly impaired until the haematocrit falls below 25 per cent. and the haemoglobin below 65 per cent. Repeated blood transfusions are dangerous in renal failure as the development of antibodies to the weak antigens of the blood sub-groups often causes haemolytic transfusion reactions (Fudenberg and Allen, 1957) and an acute deterioration of the uraemic state. If the haemoglobin concentration is above 60 per cent. it is usually better in the long run not to transfuse patients with chronic uraemia.

\section{Acknowledgments}

I wish to express my thanks to Professor M. L. Rosenheim, Professor C. E. Dent and Dr. C. J. Hodson for the illustrations.

\section{BIBLIOGRAPHY}

BAUR, A. (1957), Dtsch. med. Wschr., 82, 975.

BEESON, P. B., ROCHA, H., and GUZE, L. B. (1957), Trans. Ass. Amer. Phys., 70, 120.

BEESON, P. M. (1955), Yale F. Biol. Med., 28, 81.

BLACK, D. A. K., and EMERY, E. W. (1957), Brit. med. Bull., 13, 7.

BLAINEY, J. D. (1954), Clin. Sci., 13, 567.

Brit. med. F. (1959), i, 40.

BROD, J. (1956), Lancet, i, 973.

BULL, G. M. (1955), Ibid., i, 73 I.

CLARK, N. S. (1956), Arch. Dis. Childh., 31, 156.

DARMADY, E. M., and STRANACK, F. (1957), Brit. med. Bull. I3, 21 .

DEMING, Q. B., and LUETSCHER, J. A. (1950), Proc. Soc. exp. Biol. (N.Y.), 73, 171 .

DEROW, H. A. (1958), New Engl. f. Med., 258, 77, 124.

DEROW, H. A. (1956), Ibid., 255, I.

DENT, C. E. (1954), Exper. Med. and Surg., 12, 229.

DENT, C. E., and HODSON, C. J. (1954), Brit. F. Radiol., 27, 605

DENT, C. E., and HARRIS, H. (1956), F. Bone $\mathscr{f} t$ Surg., 38b, 204 DE NAVASQUEZ, S. (1956) $\mathcal{F}$. Path. Bact. 71, 429.

EMERSON, C. P., and BURROWS, B. A. (1949), $\mathcal{F}$. clin. Invest 28, 779.

ETTELDORF, J. N., SMITH, J. D., and JOHNSON, C. (1956) F. Pediat., 48, 129.

FARNSWORTH, E. B. (1950), Proc. Soc. exp. Biol. (N.Y.), 74, 57?

FARQUHAR, M. G., VERNIER, R. L., and GOOD, R. A. (1957), Amer. F. Path., 33, 79 I.

FREEDMAN, P., and SPENCER, A. G. (1957), Clin. Sci., 16, I I.

FUDENBERG, H., and ALLEN, F. H. (1957), New Engl. F. Med., 256, 1180 .

GARROD, L. T., SHOOTER, I. E., and CURWEN, M. P. (1954), Brit. med. F., ii, 1003

GARROD, L. P. (I959), 'Chemotherady of Infections of the Urinary 'Tract,' R.C.P., Edinburgh, Publication No. I I.

GLYNN, L. E., HOLBORROW, E. J., and JOHNSON, G. D. (1956), 手. Immunol., 76, 357.

GOLDWASSER, E., FRIED, W., and PLZAK, L. F. (1957). Trans. Ass. Amer. Phys., 70, 305.

GOODMAN, H. C., and BAXTER, J. H. (1958), Metabolism, 7, 40. HARRINGTON, M. (1953), Clin. Sci., 12, 185.

HARRINGTON, M., ROSENHEIM, M. L. (1954), Lancet, i, 7.

HARRIS, H. (1957), Brit. med. Bull., 13, 26.

HIGGINS, T. T., WILLIAMS, D. I., and NASH, E. F. (I95I), 'The Urology of Childhood,' Butterworth \& Co. Ltd., London.

HUTT, M. S. R., PINNIGER, J. L., and DE WARD ENER (1958), Quart. $\mathcal{Y}$. Med., 27, 265.

ILLINGWORTH, R. S., PHILPOTTS, M. G., and RENDLESHORT, J. (1954), Arch. Dis. Childh., 29, 55 r.

JANEWAY, C. A. (1957), Lancet, i, 197.

KARK, R. M., PIRANI, C. L., POLLAK, V. E., MEUHRCKE, R. C., and BLAINEY, J. D. (1958), Ann. intern. med., 49, $75 \mathrm{I}$. KASS, E. H. (1955), Amer. F. Med., 18, 764.

KASS, E. H. (1957), New Engl. F. Med., 256, 91 5.

KEEFER, C. S. (1957), Bull. Fohns Hopk. Hosp., 100, 107.

KIPNIS, G. P., JACKSON, G. G., DALLENBACH, F. D, and SCHOENBERGER, J. A. (1955), Arch. intern. Med., 95, 445.

KRAKOWER C. A. and GREENSPAN S. A. (1958) Arch. Path. (Chicago), 66, 364 .

LANGE, K., SLOBODY, L., and STRONG, R. (1955), Paediatrics, $15,156$.

LARAGH, J. H., HEINEMANN, H. O., and DEMARTINI, F. E. (1958), Ұ. Amer. med. Ass., 166, 145. 


\title{
A Practice of Anaesthesia
}

\author{
by W. D. WYLIE
}

M.B.(Cantab.), M.R.C.P.(Lond.), F.F.A.R.C.S.

Consultant Anaesthetist, St. Thomas's and other Hospitals

and

H. C. CHURCHILL-DAVIDSON

M.D.(Cantab.), F.F.A.R.C.S.

$x v i+1056 p p$.

327 illustrations,

1 colour plate

(1959) 105s. net

Consultant Anaesthetist, St. Thomas's and other Hospitals

\section{Forensic Medicine Observation and Interpretation by A. KEITH MANT M.D.(Lond.)}

Lecturer, Dept. Forensic Medicine, Guy's and St. Mary's Hospitals, London

\section{Practical Obstetric Problems}

(2nd edition) by IAN DONALD M.B.E., M.D.(Lond.), F.R.F.P.S.(Glas.), F.R.C.O.G. Regius Professor of Midwifery, University of Glasgow

\author{
General Pathology \\ (2nd edition) \\ Edited by SIR HOWARD FLOREY \\ M.D., F.R.C.P., F.R.S. \\ Professor of Pathology, University of Oxford
}

viii $+264 p p$.

127 illustrations

1 colour plate

(1959) 42s. net

$x v i+712 p p$.

139 illustrations

(1959) 55s. net

$x v i+932 p p$.

410 illustrations,

3 colour plates

(1958) 84s. net

49 Newman Street, London, W.

Bibliography continued from previous page-A. G. Spencer, M.D., M.R.C.P.

Lancet (1958), 2, 1215.

Lancet (1959), I, 81 .

LANGE, K., and WASSERMAN, E. (1958), F. Amer. med. Ass., $168,377$.

LOEB, E. N. (1938), 7. clin. Invest., 17, 623 .

LOGE, J. P., LANGE, R. D., and MOORE, C. V. (1958), Amer. F. Med., 24, 4.

MACKINNON, J. (1952), Lancet, 2, 12.

McDONALD, L., and GOLDBERG, B. (1957), Ibid., i, 77.

METCOFF (1957), 'Proceedings of Eighth Annual Conference on the Nephrotic Syndrome,' ed. J. Metcoff, 1957, New York, National Nephrosis Foundation.

MOSTOGI, F. K., BRUEGGE, C. F., and DIGGS (1957), A.M.A.' Arch. Path., 63, 336.

MOYER, J. H. (1954), Ann. N.Y. Acad. Sci., 59, 82.

MOYER, J. H., and MILLS, L. C. (1953), F. clin. Invest., 32, 172. MUDGE, G. H. (1958), Amer. F. Med., 24, 661.

MUEHRCKE, R. C., KARK, R. M., and PIRANI, C. L. (1955), New Engl. F. Med., 253, 537 .

MURRAY, R. S., and TRESSIDER, G. C. (1957), Brit. med. Bull., I3, 6r.

NABARRO, J. D. N., and SPENCER, A. G. (1951), Brit. med. f., ii, 393 .

OSNES, S. (1958), Ibid., 2, 1387.

PEARSE, A. G. E. (I953), 'Histochemistry, Theoretical and Applied,' Churchill, London.

PLATT, R. (1948), Quart. F. Med., 17, 83.

PLEYDELL, M. J., and HALL-TURNER, W. J. A. (1958), Brit. med. F., il, 1382 .

POUTASSE, E. F., and DUNSTAN, H. P. (1957), f. Amer. med. Ass., 165, 1521 .

- Proceedings of the Conference on Basic Mechanisms in Arterial Hypertension' (1958), Circulation, 17, 641.

RAMMELKAMP, C. H. (1955), Ann. intern. Med., 43, 51 I.

RAMMELKAMP, C. H., Jr., and WEAVER, R. S. (1953), $\mathcal{F}$. clin. Invest., 32, 345.

RHODIN, J. (1958), Amer. F. Med., 24, 661.
RICH, A. (1956), Bull. Fohns Hopk. Hosp., 98, 120.

RICHARDS, W. A., RISS, E., KASS, E.' H., and FINLAND, M. (1955), Arch. intern. Med., 96, 437.

ROBIN, E. D., and GARDNER, F. H. (1957), Trans. Ass. Amer. Phys., 70, 140.

ROSENHEIM, M. L. (1951), Ann. roy. Coll. Surg. Engl., 9, 1951. ROSENHEIM, M. L. (1954), Proc. roy. Soc. Med. 47, 628 .

ROSENHEIM, M. L., and SPENCER, A. G. (1956), Lancet, ii, 313. ROSENHEIM, M. L., SPENCER, A. G., MOULTON, R., and CATTELL, W. (1959), Proc. Ass. Phys.

SCHMIDT, W. C., and RAMMELKAMP, C. H., Jr. (1958), 'Advances in Internal Medicine,' 9,181 . SCHREINER, G. E., and BLOOMER, H. A. (1957), New Engl.
Ұ. Med., 257, roI6.

SCOWEN, C. F., BADENOCH, A. W., and SHOOTER, R. A. (1057), Brit. F. Urol. 20, 140.

SEEGAL, D., and LYTTLE, J. D. (1933), Proc. Soc. exp. Biol., 31, 2II.

SELDINGER, S. I. (1953), Acta radiol. (Stockh.), 39, 368.

SHAW, G. (I959), Lancet, i, 15.

SIMPSON, S. A., TAIT, J. F., and BUSH, I. E. (1952)

SLATER, J. D. H., HEFFRON, P. F., VERNET, A., and NABARRO, J. D. N. (1959), Lancet, i, 173

SMITH, H. (1956), F. Urol., 76, 683.

SPENCER, A. G. (1950), Nature, 166, 32.

SPENCER A. G. and FRANGLEN G. T. (1952), Lancet, i, 190. SQUIRE, J. R. (1955), 'Advances in Internal Medicine,' 7, 201, ed. W. Dock and I. Snapper, Year Book Publishers.

STANBURY, S. W. (1957), Brit. med. Bull., 13,57.
STANBURY, S. W. (1958), 'Advances in Internal Medicine,' 23I, ed.'W. Dock and I. Snapper, Year Book Publishers, New York.

STEINER, R. E. (1957), Brit. med. Bull., 13, 64.

TAGGART, J. V. (1058), Amer. F. Med., 24, 66r.

WAKSMAN, S. A. (1958), ' Neomycin: Its Nature and Practical Application,' Bailliere, 'Tindall \& Cox, London.

WILMERS, M. J., CUNLIFFE, A. C., and WILLIAMS, R. E. O. (1954), Lancet, ii, 17.

WILSON, C. (1953), Ibid., ii, 632. WILSON, C., and ABRAHAMS ,D. G. (1957), Brit. med. Bull.,
13, 39. 